JOURNAL OF AGRICULTURE AND APPLIED BIOLOGY

2020, Vol. 1, No. 2, $86-91$

http://dx.doi.org/10.11594/jaab.01.02.06

Research Article

\title{
Effect of silver nanoparticles, synthesized from fleshy stem and leaves extract of Brassica campestris L., on Alternari lini inhibition
}

\author{
Syed Awais Hussain Shah
}

Department of Botany, Mohi-ud-din Islamic University, Nerian Sharif AJK Pakistan

Article history:

Submission 13 October 2020

Accepted 12 November 2020

Published 28 December 2020

Keywords:

Alternaria lini

Antifungal activity

Brassica campestris L.

Linseed

Screening electron microscopy

${ }^{*}$ Corresponding author:

E-mail:

uok6474@gmail.com

\begin{abstract}
Several fungal pathogens showed resistance against pesticides, plant mediated synthesized silver nanoparticles have been recognized as effective against them. The present research work was an attempt to synthesize silver nanoparticles by using fleshy stem and leaves extract of Brassica compestris L. from silver nitrate, which reduces it to synthesized silver nanoparticles. Biosynthesized AgNP's were characterized by different techniques like UV-visible spectrophotometry and Field Emission Scanning Electron Microscopy and fungal inhibitory activity by well diffusion method. The colour change of solution indicated the synthesis of silver nanoparticles. UV-visible spectrophotometer showed the peak between 415 to $455 \mathrm{~nm}$ for fleshy stem and leaves extract of $B$. compestris and Field Emission Scanning Electron Microscope analysis revealed that spherical shaped nanoparticles with size 20-65 nm. These synthesized nanoparticles showed inhibitory activity against fungi, Alternaria lini, a linseed blight pathogen which causes linseed blight disease in Linum usitatissimum L. The $30 \mu \mathrm{l}$ concentrations of silver nanoparticles had showed significant inhibition to growth of $A$. lini. These findings may suggest AgNP's synthesized by $B$. compestris used against plant pathogenic fungi.
\end{abstract}

\section{Introduction}

Green synthesis of metallic nanoparticles is an emerging aspect of modern nanotechnology. It is an eco-friendly method of synthesis of nanoparticles (Raja et al., 2018). Besides this it is easy, economical and time saving method. It is reported by various researchers that Silver nanoparticles have great antibacterial (Asghar et al., 2018; Khatami et al., 2018; Gokak \& Taranath, 2014), antifungal (Asghar et al., 2018) (Khatami et al., 2018), antiviral (Rogers et al., 2008), anticancer (Khatami et al., 2018), anti- inflammatory (Nadworny et al., 2010) and antioxidant activity (Kharat \& Mendhulkar, 2016; Sivakumar et al., 2015). Different parts of the plant such as: root, stem, leaves, fruit and bark are used for the production of nanoparticles (Shanmuganathan et al., 2017) due to the composition of various biomolecules (carbohydrates, proteins, phenols, ketones, etc) in them and capabale to reduce, stabilize and maintain their shape and size (Mariselvam et al., 2014).

Brassica campestris L. is an important plant belongs to family Brassicaceae. Commonly 
known as sarso, yellow mustard, etc. It is used as a food for human and animals in Pakistan.

Linum usitatissimum L. known as common linseed or Flax, belongs to family Linnaceae, has cultivated world-wide due to its importance in medicine and industry as immunomodulatory, antioxidant, anti-tumor, antimicrobial, anti-inflammatory and analgesic, etc. (Ansari et al., 2019). At the time of its cultivation farmers face various problems like disease management. Linseed Blight disease that caused by Alternaria lini Dey, adversely effects and reduces the yield of linseed. This work was an attempt for the exploration of antifungal potential against linseed blight of phyto-synthesized silver nanoparticles from fleshy stem and leaves extract of Brassica campestris $\mathrm{L}$.

\section{Materials and Methods Sample collection and identification}

Fully young plants of Brassica campestris $\mathrm{L}$. were collected from the fields of Sarhota No. 2, Tehsile and District Kotli AJK Pakistan, and then brought at University of Kotli for identification. Identification was done with the help of available literature and was confirmed from flora of Pakistan.

\section{Preparation of fleshy stem and leaves extract}

Brassica compestris were collected from the field and brought into the lab where they were rinsed with tap water for the removal of dust and other particles. Fleshy stem and leaves were then removed. To make aqueous extract of $B$. compestris, about $10 \mathrm{~g}$ of fleshy stem and leaf sample was mixed in $100 \mathrm{ml}$ distilled water and boiled in water bath for 20 minutes at about $60{ }^{\circ} \mathrm{C}$. Then, extract was cooled and filtered using Whatman No. 1, filter paper. Filtrate than stored and used for the further reactions.

\section{Silver nanoparticles synthesis}

Methods described by Meenakshisundaram et al. (2013) and Thilagam et al. (2013) were followed with appropriate changes for the synthesis of silver nanoparticles from the fleshy stem and leaves extract of $B$. compestris, the extract was reacted with silver nitrate $\left(\mathrm{AgNO}_{3}\right)$ solution. About $10 \mathrm{ml}$ extract added to the 90 $\mathrm{ml}$ silver nitrate solution. This reaction mixture was then kept in dark condition at room temperature. The bio-reduction of silver particles by fleshy stem and leaves extract was scrutinized by measuring the UV-visible spectra of the reaction medium at 200 to $800 \mathrm{~nm}$. Complete bio-reduced sample was than centrifuged at $10000 \mathrm{rpm}$ for 20 minutes at $4{ }^{\circ} \mathrm{C}$. The pellet was collected and preserved for further reactions.

\section{FE-SEM analysis}

Field Emission Scanning Electron Microscope (Model: JSM-7800F) was used to observe the finest' structural morphology of nano materials of Silver at $1,000,000 \mathrm{x}$ magnification with $1 \mathrm{~nm}$ resolution.

\section{Antifungal activity}

Infected plant of linseed was collected from field and pathogen, Alternaria lini was screened and cultured on CDA media, according to method described by Savithramma \& Rao (2011). Then, material from this culture media was used for the study of inhibitory action of silver nanoparticles. Well diffusion method described by Perez et al. (1990) was followed for the study of antifungal activity. The agar plates were inoculated by spreading the spores of the Alternaria lini over the entire agar surface. Then these $6 \mathrm{~mm}$ wells were punched and different concentrations viz $10 \mu \mathrm{l}, 20 \mu \mathrm{l}$, and $30 \mu \mathrm{l}$ of the nanoparticles were loaded in each plate. After incubation, twenty-four hours, zone of inhibition of $A$. lini was recorded.

\section{Results and Discussion Visual identification}

Colour change of $1 \mathrm{mM}$ silver nitrate $\left(\mathrm{AgNO}_{3}\right)$ solution indicated that the synthesis of nanoparticles, from colourless to blakish brown after reaction with fleshy stem and leaves extract of $B$. compestris (as shown in Figure 1). 

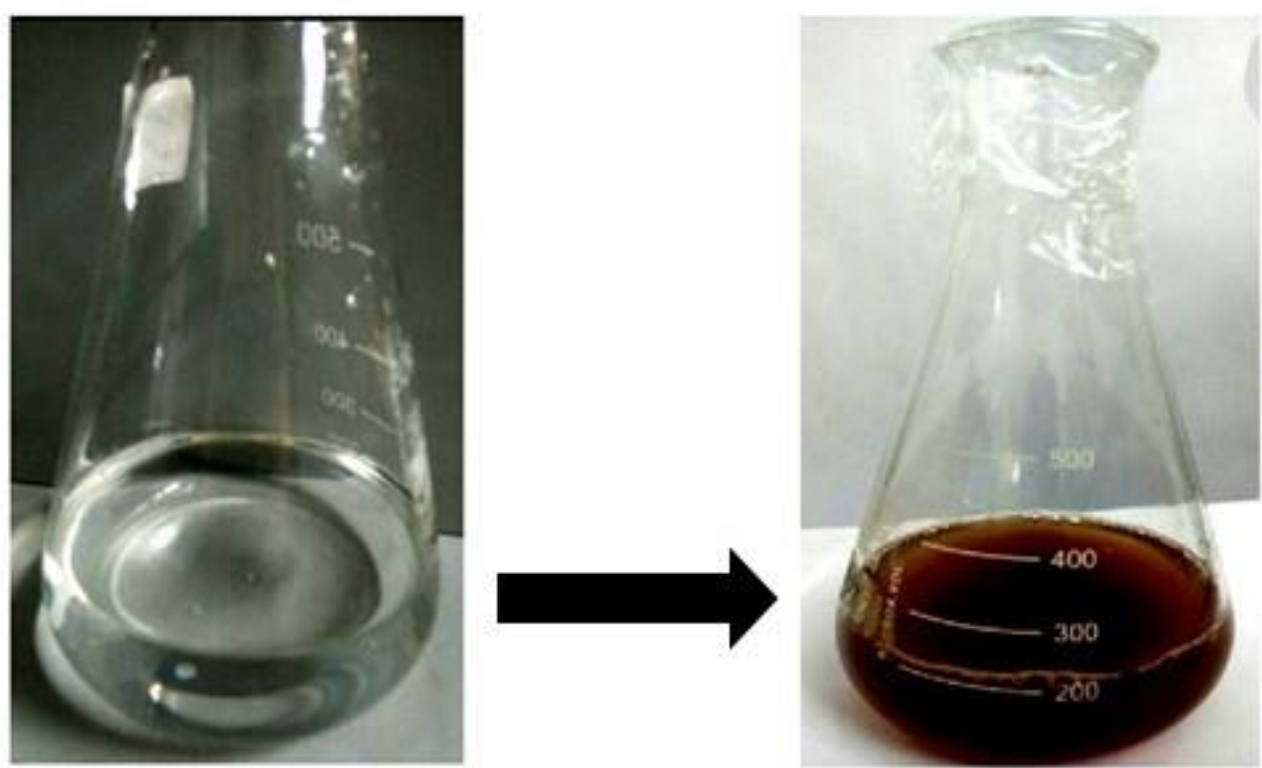

Figure 1. Visual identification of synthesis of $\mathrm{AgNP}\left(\mathrm{AgNO}_{4}\right.$ solution colour changes from colourless to blackish brown after reaction with fleshy stem and leaves extract of B. compestris)

\section{UV-Visible spectroscopy}

Silver nanoparticles formation was confirmed by UV-visible spectrophotometer. Characteristics surface plasmone absorption peak was observed between 415 to $455 \mathrm{~nm}$ by UV-visible spectrophotometer (as shown in
Figure 2). In the literature, absorption peak of nanoparticles is observed at 400 to $450 \mathrm{~nm}$ (Ajitha et al., 2015) which is specific for silver nanoparticles (Dzul-Erosa et al., 2018; Patil \& Kim, 2016).

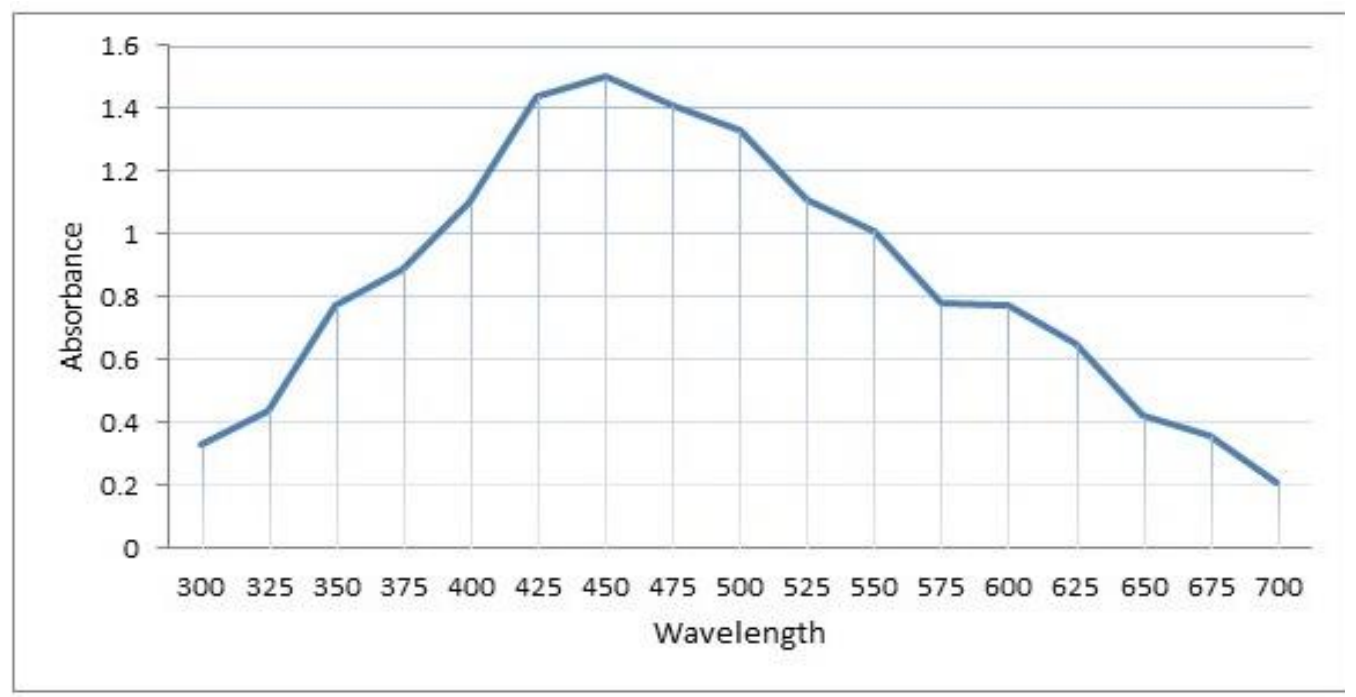

Figure 2. UV-visible spectrograph of silver nanoparticles

\section{FE-SEM analysis}

Size and shape of nanoparticles were confirmed through Field Emission Scanning Electron Microscope (FE-SEM) analysis. FE-SEM analysis revealed that the shapes of nanoparticles were spherical and their size ranges between 20 to $65 \mathrm{~nm}$ (as shown in Figure 3). Most nanoparticles were distributed randomly in the form of clumps. 


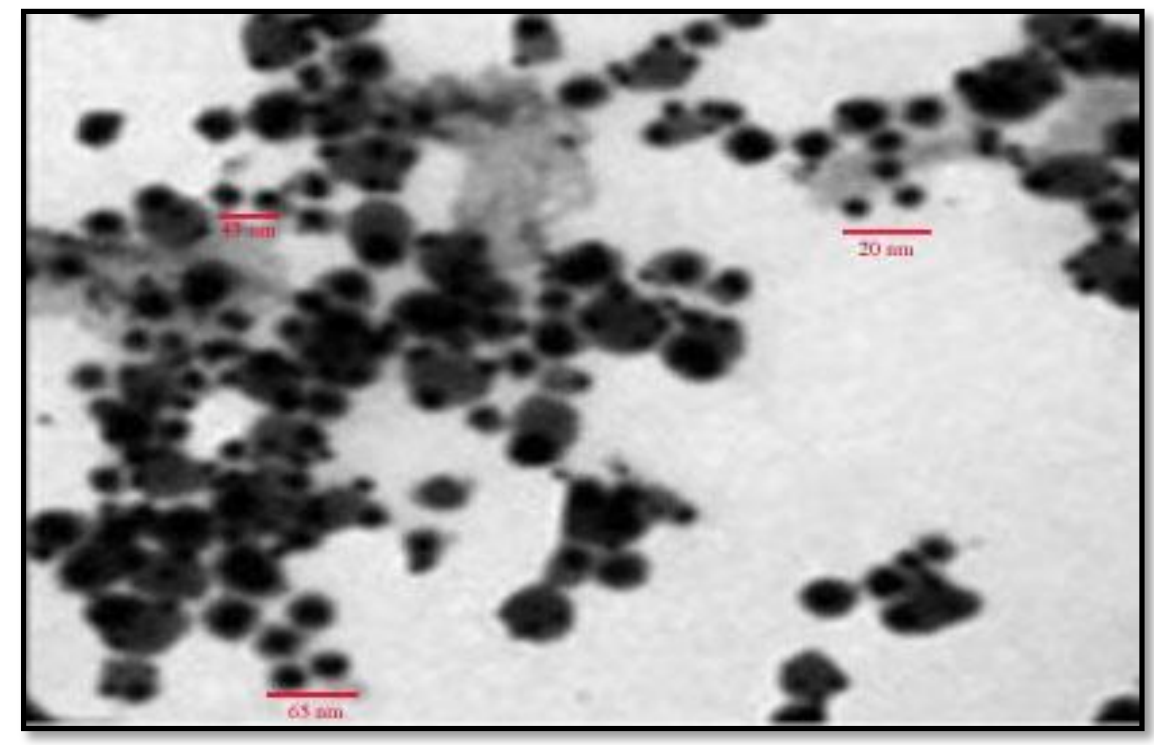

Figure 3. FE-SEM micrograph of silver nanoparticles

\section{Antifungal activity}

Silver (Ag) nanoparticles synthesized from fleshy stem and leaves extract of $B$. compestris had showed the potential to inhibit the growth of fungal strain, Alternaria lini. Different concentrations i.e. $10 \mu \mathrm{l}, 20 \mu \mathrm{l}, 30 \mu \mathrm{l}$ of nanoparti- cles were applied on culture media of fungi, $A l$ ternaria lini. It was observed that $30 \mu \mathrm{l}$ concentrations of nanoparticles were more effective in inhibiting the growth of Alternaria lini (as shown in Table 1).

Table 1. Fungal zone of inhibition by applying different concentration of AgNP's

\begin{tabular}{ccc}
\hline Sr. \# & Concentration of AgNP's used & Inhibition zone \\
\hline 1 & $10 \mu \mathrm{l}$ & $7 \mathrm{~mm}$ \\
\hline 2 & $20 \mu \mathrm{l}$ & $11 \mathrm{~mm}$ \\
\hline 3 & $30 \mu \mathrm{l}$ & $13 \mathrm{~mm}$
\end{tabular}

In the last few decades, silver nanoparticles are widely used against various pathogens including bacteria and fungi. Due to their diverse applications in certain other fields such as: agriculture, drug development and in clinical research, much attention has been given on their eco-friendly and economical synthesis. Plant based approaches for their synthesis are ecofriendly and economical (Prabhu \& Poulose, 2012; Kathiresan, et al., 2019; Pasa et al., 2019). Phytochemicals in plants acts as reducing agent. They reduce the toxic Ag to nontoxic Ag nanoparticles (Kumar et al., 2017). In present work, Silver nanoparticles were synthesised from B. compestris and from UV-visible spectroscopic analysis maximum absorption peak was observed at 415 to $455 \mathrm{~nm}$. Our result, resembles with the results of Asha et al. (2017), Rajeshkumar et al. (2017), Iqbal and Bakht (2019) and Pasa et al. (2019), their results showed maximum absorption peak between 400 to 450 nm.

The productivity of linseed crop had reduced due to various diseases caused by various pathogens. In sub-continent especially in Pakistan and India the productivity of linseed crop is very low due to pathogenic attack. A fungal species, Alternaria lini reduced the yield of linseed crop 25 to $60 \%$ alone annually of the total yield (Chauhan et al., 1975). The silver nanoparticles synthesized from fleshy stem and leaves extract of $B$. compestris are useful in 
management of the A. lini, pathogen and boosting the yield of linseed crop. These nanoparticles might be used against various other pathogens and in agricultural industries for the development of fungicides.

\section{Conclusion}

Silver nanoparticles were synthesized from fleshy stem and leaves extract of Brassica compastris L. and confirmed by UV-visible Spectroscopy and FE-SEM analysis. The inhibitory activity of biosynthesized silver nanoparticles against Alternaria lini was then evaluated. Our results showed significant inhibitory activity against $A$. lini. Thus, the findings of this study could be adopted as a tool for green synthesis of silver nanoparticles, having significant fungal inhibiting potential. These nanoparticles may be used against various fungal pathogens to enhance the yield quantity and quality of cereal crops.

\section{Acknowledgement}

The author is thankful to the Department of Botany, Mohi-ud-din Islamic University, Nerian Sharif AJK-Pakistan and Department of Botany, University of Kotli, Kotli AJK-Pakistan for providing lab facilities for this research work.

\section{Conflict of Interest}

Author declared no conflict of interest.

\section{References}

Ajitha, B., Reddy, Y. A. K., \& Reddy, P. S. (2015). Green synthesis and characterization of silver nanoparticles using Lantana camara leaf extract. Materials Science and Engineering: C, 49, 373-381. https://doi.org/10.1016/i.msec.2015.01.035

Ansari, R., Zarshenas, M. M., \& Dadbakhsh, A. H. (2019). A review on pharmacological and clinical aspects of Linum usitatissimum L. Current Drug Discovery Technologies, 16 (2), 148-158. https://doi.org/10.2174/15701638156661805211 $\underline{01136}$

Asghar, M. A., Zahir, E., Shahid, S. M., Khan, M. N., Asghar, M. A., Iqbal, J., \& Walker, G. (2018). Iron, copper and silver nanoparticles: Green synthesis using green and black tea leaves extracts and evaluation of anti- bacterial, antifungal and aflatoxin B1 adsorption activity. $L W T, 90,98-107$.

https://doi.org/10.1016/j.lwt.2017.12.009

Asha S., Asha A., \& Rajeshkumar S. (2017). Evaluation of phytochemical constituents and antimicrobial activity of silver nanoparticle synthesized Ipomoea nil agains selected pathogens. Asian Journal of Pharmaceutical and Clinical Research, 10(3), 183.

https://doi.org/10.22159/ajpcr.2017.v10i3.15986

Dzul-Erosa, M. S., Cauich-Díaz, M. M., Razo-Lazcano, T. A., Avila-Rodriguez, M., Reyes-Aguilera, J. A., \& González-Muñoz, M. P. (2018). Aqueous leaf extracts of Cnidoscolus chayamansa (Mayan chaya) cultivated in Yucatán México. Part II: Uses for the phytomediated synthesis of silver nanoparticles. Materials Science and Engineering: C, 91 (8), 838-852.

https://doi.org/10.1016/i.msec.2018.06.007

Erdogan, O., Abbak, M., Demirbolat, G. M., Birtekocak, F., Aksel, M., Pasa, S., \& Cevik, O. (2019). Green synthesis of silver nanoparticles via Cynara scolymus leaf extracts: The characterization, anticancer potential with photodynamic therapy in MCF7 cells. PLOS ONE, 14 (6), Article e0216496.

https://doi.org/10.1371/journal.pone.0216496

Gokak, I. B., \& Taranath, T. C. (2014). Phytosynthesis of silver nanoparticles using leaf extract of Wattakaka volubilis (L. f.) Stapf. and their antibacterial activity. International Journal of Science, Environment and Technology, 3 (1), 93-99.

http://www.ijset.net/journal/231.pdf

Iqbal, M., \& Bakht, J. (2019). Phytosynthesis of silver nanoparticles from $A$. jacquemontii extract, their characterization and antimicrobial potential. Pakistan Journal of Botany, 51(5), 1853-1857. https://doi.org/10.30848/pjb2019-5(37)

Kharat, S. N., \& Mendhulkar, V. D. (2016). "Synthesis, characterization and studies on antioxidant activity of silver nanoparticles using Elephantopus scaber leaf extract." Materials Science and Engineering: C, 62(1), 719-724. https://doi.org/10.1016/i.msec.2016.02.024

Khatami, M., Sharifi, I., Nobre, M. A. L., Zafarnia, N., \& Aflatoonian, M. R. (2018). Waste-grass-mediated green synthesis of silver nanoparticles and evaluation of their anticancer, antifungal and antibacterial activity. Green Chemistry Letters and Reviews, 11(2), 125-134.

https://doi.org/10.1080/17518253.2018.1444797 
Mariselvam, R., Ranjitsingh, A. J. A., Usha Raja Nanthini, A., Kalirajan, K., Padmalatha, C., \& Mosae Selvakumar, P. (2014). Green synthesis of silver nanoparticles from the extract of the inflorescence of Cocos nucifera (Family: Arecaceae) for enhanced antibacterial activity. Spectrochimica Acta Part A: Molecular and Biomolecular Spectroscopy, 129, 537-541.

https://doi.org/10.1016/i.saa.2014.03.066

Menon, S., Agarwal, H., Kumar, S. R., \& Kumar, S. V. (2017). Green synthesis of silver nanoparticles using medicinal plant Acalypha indica leaf extracts and its application as an antioxidant and antimicrobial agent against foodborne pathogens. International Journal of Applied Pharmaceutics, 9(5), 42. https://doi.org/10.22159/ijap.2017v9i5.19464

Nadworny, P. L., Wang, J., Tredget, E. E., \& Burrell, R. E. (2010). Anti-inflammatory activity of nanocrystalline silver-derived solutions in porcine contact dermatitis. Journal of Inflammation, 7(1), 13. https://doi.org/10.1186/1476-9255-7-13

Patil, M. P., \& Kim, G.-D. (2016). Eco-friendly approach for nanoparticles synthesis and mechanism behind antibacterial activity of silver and anticancer activity of gold nanoparticles. Applied Microbiology and Biotechnology, 101(1), 79-92. https://doi.org/10.1007/s00253-016-8012-8

Perez, C., Pauli, M., \& Bazerque, P. (1990). An antibiotic assay by agar well diffusion method. Acta Biologiae et Medicinae Experimentalis, 15, 113-115.

Prabhu, S., \& Poulose, E. K. (2012). Silver nanoparticles: mechanism of antimicrobial action, synthesis, medical applications, and toxicity effects. International Nano Letters, 2(1). https://doi.org/10.1186/2228-5326-2-32

Raja, A., Ashokkumar, S., Pavithra Marthandam, R., Jayachandiran, J., Khatiwada, C. P., Kaviyarasu, K., Ganapathi Raman, R., \& Swaminathan, M. (2018). Ecofriendly preparation of zinc oxide nanoparticles using Tabernaemontana divaricata and its photocatalytic and antimicrobial activity. Journal of Photochemistry and Photobiology B: Biology, 181, 53-58. https://doi.org/10.1016/i.jphotobiol.2018.02.011

Ravichandran, V., Sumitha, S., Vasanthi, S., Shalini, S., Chinni, S., B. Gopinath, S., Kathiresan, S., \& Anbu, P. (2019). Durio zibethinus rind extract mediated green synthesis of silver nanoparticles: Characterization and biomedical applications. Pharmacognosy
Magazine, 15 (60), 52.

https://doi.org/10.4103/pm.pm_400_18

Rogers, J. V., Parkinson, C. V., Choi, Y. W., Speshock, J. L., \& Hussain, S. M. (2008). A preliminary assessment of silver nanoparticle inhibition of monkeypox virus plaque formation. Nanoscale Research Letters, 3(4), 129-133. https://doi.org/10.1007/s11671-0089128-2

Savithramma, \& Rao, L. (2011). Antifungal efficacy of silver nanoparticles synthesized from the medicinal plants. Der Pharma Chemica, 3(3), 364-372.

https://www.derpharmachemica.com/pharmachemica/antifungal-efficacy-of-silver-nanoparticles-synthesized-from-themedicinal-plants.pdf

Shanmuganathan, R., MubarakAli, D., Prabakar, D., Muthukumar, H., Thajuddin, N., Kumar, S. S., \& Pugazhendhi, A. (2017). An enhancement of antimicrobial efficacy of biogenic and ceftriaxone-conjugated silver nanoparticles: green approach. Environmental Science and Pollution Research, 25(11), 1036210370. https://doi.org/10.1007/s11356-0179367-9

Singh, H. K., Singh, R. B., \& Parmar, A. (2014). Yield loss assessment due to alternaria blight and its management in linseed. Pakistan Journal of Biological Sciences, 17 (4), 511-516. https://doi.org/10.3923/pjbs.2014.511.516

Sivakumar, T., Rathimeena, T., Thangapandian, V., \& Shankar, T. (2015). Silver nanoparticles synthesis of Mentha arvensis extracts and evaluation of antioxidant properties. Bioscience and Bioengineering, 1(2), 22-28. http://files.aiscience.org/journal/article/pdf/70010022.pdf

Sivaranjani, K., \& Meenakshisundaram, M. (2013). Biological synthesis of silver nanoparticles using Ocimum basillicum leaf extract and their antimicrobial activity. International Research Journal of Pharmacy, 4 (1), 225-229. https://iriponline.com/admin/php/uploads/1602 pdf.pdf

Thilagam, M., Tamilselvi, A., Chandrasekeran, B., \& Rose, C. (2013). Phytosynthesis of silver nanoparticles using medicinal and dye yielding plant of Bixa orellana L. leaf extract. Journal of Pharmaceutical and Scientific Innovation, 2(4), 9-13. https://doi.org/10.7897/2277-4572.02441 